\title{
Novel Imaging Techniques, Integrated with Mineralogical, Geochemical and Microbiological Characterization to Determine the Biogeochemical Controls....
}

\author{
Lloyd, Jonathan R. \\ University of Manchester
}

\begin{abstract}
RESULTS TO DATE: HYPOTHESIS 1. TC(VII) will be reduced and precipitated in FRC sediments under anaerobic conditions in batch experiments (progressive microcosms). The complementary microcosm experiments using low pH/nigh nitrate sediments from 3 (near FW 009) are imminent, with the sediment cores already shipped to Manchester. HYPOTHESIS 2. Tc(VII) reduction and precipitation can be visualized in discrete biogeochemical zones in sediment columns using 99mTc and a gamma-camera. Preliminary experiments testing the use of $99 \mathrm{mTc}$ as a radiotracer to address hypotheses 2 and 3 have suggested that the $99 \mathrm{mTC}$ associates with $\mathrm{Fe}(\mathrm{II})$-bearing sediments in microcosms and stratified columns containing FRC sediments. Initial proof of concept microcosms containing Fe(II)-bearing, microbiallyreduced FRC sediments were spiked with $99 \mathrm{mTC}$ and imaged using a gamma-camera. In comparison with oxic controls, 99mTc was significantly partitioned in the solid phase in Fe(III)-reducing sediments in batch experiments. Column experiments using FRC background area soil with stratified biogeochemical zones after stimulation of anaerobic processes through nutrient supplementation, suggested that 99mTc transport was retarded through areas of Fe(III) reduction. HYPOTHESIS 3. Sediment-bound reduced $99 \mathrm{mTc}$ can be solublized by perturbations including oxidation coupled to biological nitrate reduction, and mobilization visualized in real-time using a gamma-camera. Significant progress has been made focusing on the impact of nitrate on the biogeochemical behaviour of technetium. Additions of $100 \mathrm{mM}$ nitrate to FRC sediment microcosms, which could potentially compete for electrons during metal reduction, inhibited the reduction of both $\mathrm{Fe}(\mathrm{III})$ and $\mathrm{Tc}(\mathrm{VII})$ completely. Experiments have also addressed the impact of high nitrate concentrations on $\mathrm{Fe}(\mathrm{II})$ and $\mathrm{Tc}(\mathrm{IV})$ in pre-reduced sediments, showing no significant resolubilization of Tc with the addition of $25 \mathrm{mM}$ nitrate. A parallel set of experiments addressing the impact of aerobic conditions on the stability/solubility of $\mathrm{Fe}(\mathrm{II})$ and Tc(IV), found $80 \%$ resolubilization of the Tc. Column experiments exploring this behaviour are being planned. HYPOTHESIS 4 The mobility of $99 \mathrm{mTc}$ in the sediment columns can be modelled using a coupled speciation and transport code. Microbiological and geochemical characterization of the column experiments is ongoing and transport and geochemical modeling experiments are being planned.
\end{abstract}

DELIVERABLES: Report of products produced: Zachara, J. and Lloyd, J.R. (2005) "What are the major research needs and approaches for evaluating reoxidation processes" Report for breakout session at DOE NABIR annual PI meeting. Burke I.T., Boothman C., Lloyd J.R., Livens F.R., Mortimer R.J.M. and Morris K. (in submission) Biogeochemical redox cycling of technetium in sediments. Environmental Science and Technology. Lloyd JR (2005) Mechanisms and environmental impact of microbial metal reduction. In: Gadd GM, Semple KT and Lappin-Scott HM (eds). Micro-organisms and earth systems advances in geomicrobiology, Vol 65. Cambridge: Cambridge University Press, pp. 273-302. Lloyd J.R., Renshaw J.C., May I., Livens F.R., Burke I.T., Mortimer R.J.M. and Morris K. (2005) Biotransformation of actinides: Microbial reduction of actinides and fission products. Journal of Nuclear and Radiochemical Science. 6 (1) 17-20. Lloyd, J.R. and Renshaw, J.C. Microbial Transformations of Radionuclides: Fundamental Mechanisms and Biogeochemical Implications (2005) in "Biogeochemical Cycles", Vol. 43 of Met. Ions Biol. Syst. M. Dekker, New York. pp. 205-240. Burke I.T., Boothman C., Lloyd J.R., Mortimer R.J.M., Livens F.R. and Morris K. (2005) Effects of progressive anoxia on the solubility of technetium in sediments. ES\&T 39 (11) 4109-4116. Burke I.T., Mortimer R.J.M., Morris K., Boothman C., Livens F.R. and Lloyd J.R. (2005) How microbial processes in estuarine sediments can control the mobility of the radionuclide, technetium. Royal Society of Chemistry, Environmental Chemistry Group Bulletin (July) 2-4. Lloyd, J.R., Anderson, R.T., Macaskie, L.E. (2005) Bioremediation of metals and radionuclides. In "Bioremediation" Ed by R.Atlas and J. Philp. ASM Press Washington pp 293-317. Lloyd J.R., Lovley, D.R., Macaskie, L.E. (2004) Biotechnological application of metal-reducing microorganisms. Advances in Applied Microbiology, 53: 85-128. Lloyd JR (2003) Microbial reduction of metals and radionuclides. FEMS 
Microbiology Reviews. 27: 411-425. Invited Conference Presentations: Lloyd, J.R. "New uses for old enzymes; mechanisms, environmental impact and biotechnological potential of microbial metal reduction". Society for General Microbiology, Keele University, UK (September 2005) Lloyd, J.R. "Anoxic redox transformations of metals and radionuclides; electron transfer at the mineral-microbe interface". The Joint International Symposia for Subsurface Microbiology (ISSM) and Environmental Biogeochemistry (ISEB), Jackson Hole, WY, USA (August 2005) Lloyd, J.R. "Geomicrobiology; studying microbial life at the bio-geo interface". North-west Microbiology Group Meeting, Manchester, UK (January 2005) Lloyd, J.R. "Microbial reduction of radionuclides". Symposium on Interactions of Heavy Elements with Microorganisms, Tokai, Japan (2004) Lloyd, J.R. "Biotechnology and the nuclear fuel cycle". European Meeting for Biotechnologies, Marseille, France (2004) Lloyd, J.R. "Microbial reduction of metals and radionuclides of environmental concern". Biometals, Garmisch Partenkirchen, Germany (2004) McBeth, J. M. "Biogeochemical controls on technetium mobility in sediments". The University of Manchester, UK (February 2004) Burke I. T., Lloyd J. R. et al. (2004). Biogeochemical redox cycling of technetium. Royal Society of Chemistry, Radiochemical Group AGM, Lincoln, UK. Grant Proposals (funded): CCLRC Daresbury, beamtime award number 42053. Poster Presentations: McBeth, J.M., Lear, G., Morris, K., Burke, I.T., Livens, F.R., Ellis, B., Lawson, R.S., Lloyd, J.R. Anoxic cycling of technetium in aquifer sediments; a multidisciplinary study. Society for General Microbiology, 157th Meeting. Keele, UK (September 2005) Burke I. T., Boothman C., Lloyd J. R., Mortimer R. J. G., Livens F. R. and Morris K. Technetium solubility during the onset of progressive anoxia. Society for General Microbiologists, 157th Meeting, Keele, UK (September 2005) Morris K., Lloyd J. R., Burke I. T., Boothman C., Livens F. R. and Mortimer, R. J. G. Biogeochemical redox cycling of technetium in estuarine sediments. Society for General Microbiologists, 157th Meeting, Keele, UK (September 2005) Boothman C., Burke I.T., Morris K. and Lloyd J.R. Anoxic biogeochemical cycling of iron; characterisation of a stable microbial consortium coupling anoxic oxidation of Fe(II) to nitrate reduction. Society for General Microbiologists, 157th Meeting, Keele, UK (September 2005) McBeth, J.M., Lear, G., Morris, K., Burke, I.T., Livens, F.R., Ellis, B., Lawson, R.S., Lloyd, J.R. Anoxic cycling of technetium in aquifer sediments; a multidisciplinary study combining geochemical, microbiological and novel imaging techniques. The Joint International Symposia for Subsurface Microbiology (ISSM 2005) and Environmental Biogeochemistry (ISEB XVII). Jackson Hole, WY, USA (August 2005) Lloyd, J.R., McBeth, J.M., Lear, G., Morris, K., Burke, I.T., Livens, F.R., Ellis, B., Lawson, R.S. Investigation of technetium redox cycling in FRC background sediments using EXAFS and Gamma Camera Imaging. NABIR P.I. Meeting, Warrenton, VA, USA (April 2005) McBeth, J.M., Lear, G., Morris, K., Burke, I.T., Livens, F.R., Lloyd, J.R. Redox cycling of technetium in aquifer sediments. Mineralogical Society Winter Meeting, Bath, UK (January 2005) Burke I. T., Boothman C., Lloyd J. R., Livens F. R., Mortimer, R. J. G. and Morris K. Reoxidation and remobilisation of technetium from Tcradiolabeled sediments. Mineralogical Society Winter Meeting, Bath, UK (January 2005) Burke I. T., Boothman C., Lloyd J. R., Mortimer R. J. G. and Morris K. Reductive precipitation of TcO4- in estuarine sediments. Mineralogical Society Winter Meeting, Bath, UK (January 2005) Burke I. T., Boothman C., Lloyd J. R., Livens F. R., Mortimer R. J. G. and Morris K. Technetium remobilisation during the reoxidation of Tc-radiolabeled sediments. VM Goldschmidt Geochemistry, Copenhagen, Denmark (2004) Morris K., Burke I. T., Boothman C., Lloyd J. R. and Mortimer R. J. G. Technetium solubility during the onset of progressive anoxia. VM Goldschmidt Geochemistry, Copenhagen, Denmark (2004) Lloyd, J.R., McBeth, J.M., Livens, F.R., Bryan, N.D.., Ellis, B., Burke, I.T., Morris, K. Biogeochemical controls on technetium mobility in FRC sediments. NABIR P.I. Meeting, USA. (2004) Burke I. T., Boothman C., Lloyd J. R., Mortimer R. J. G. and Morris K. Biogeochemistry of technetium: progressive anoxia microcosm results. 6th International Symposium on Environmental Geochemistry, Edinburgh, UK (2003) 